\title{
FIFA World Cup 2014 on Twitter and Facebook: more from less or less from more?
}

\author{
Ivo Neto \& Felisbela Lopes \\ CECS - Uminho \\ E-mail: ivoneto88@gmail.com/felisbeladics.uminho.pt
}

\begin{abstract}
The last FIFA World Cup in Brazil pre- mobile platform, it becomes necessary to sented the ambition of a global event, referring both to the number of audiences and the number of platforms involved in its coverage. Taking the advantages promoted by social media platforms and mobile technologies, media companies had the opportunity to try new strategies in a truly ambient information reality. Taking into account the development of Twitter, assuming itself as an informative and promote a further reflection about the impact of social media in the field of journalism. Applying this research to sport we follow other analyses made about political issues. In this study, we have analyzed 3195 post on Twitter and 665 on Facebook, made by media outlets from seven different countries, during the coverage of 32 matches of the World Cup in Brazil, in June and July 2014.
\end{abstract}

Keywords: social media; ambient information; produser; FIFA WORLD Cup; power and participation.

Data de submissão: 13-01-2016. Data de aprovação: 23-10-2016.

A Revista Estudos em Comunicação é financiada por Fundos FEDER através do Programa Operacional Factores de Competitividade - COMPETE e por Fundos Nacionais através da FCT - Fundação para a Ciência e a Tecnologia no âmbito do projeto Comunicação, Filosofia e Humanidades (LabCom.IFP) UID/CCI/00661/2013. 


\section{FIFA World Cup 2014 no Twitter e Facebook: mais com menos ou menos com mais?}

\section{RESUMO}

O último campeonato do Mundo FIFA, que se realizou no Brasil, apresentou a ambição de um evento global, tanto ao nível das audiências como nas plataformas utilizadas na sua cobertura. Aproveitando as vantagens promovidas pelas plataformas de media social e os periféricos móveis, as empresas mediáticas tiveram a oportunidade de experimentar novas estratégias, numa realidade marcada pela ambient information. Tendo em conta o desenvolvimento do Twitter, que se assume cada vez mais como uma plataforma informativa móvel, é necessário refletir sobre o impato das media sociais no campo do jornalismo. Aplicando esta pesquisa ao desporto, seguimos outras análises feitas em questões relacionadas com a política. Neste estudo, analisámos 3195 posts no Twitter e 665 no Facebook feitos por meios de sete países diferentes, durante a cobertura de 32 partidas do Campeonato do Mundo do Brasil, em junho e julho de 2014.

Palavras-chave: media sociais; informação ambiente; produser; FIFA WORLD Cup; poder e participação.

\section{The World Cup of Multiple Platforms: \#TAKe PART OF \#The} Global Stadium

IFA World Cup, which takes place every four years, is the most awaited 1 moment by all football lovers. For two years, teams from every continent compete for 32 places, dreaming about the presence in this football's world stage. In 2014 it was Brazil to receive stars like Cristiano Ronaldo, Lionel Messi and Arjen Robben. For over a month, the full stadiums are followed by millions of viewers, making this competition a truly global event ${ }^{1}$.

1. Of the 3 million tickets sold for the final stage of the competition, nearly $40 \%$ wer e allocated to foreigners. To this number we may join the spectators from countries not qualified to this stage of the competition. According to the report produced by FIFA, on the very first journey in which 32 teams were still competing, a number of records were broken regarding the television coverage. For example, 27 million TV viewers watched the match between Italy and England, beating records of audience of these two countries. Also the United States, where football still seeks to achieve the popularity of sports like American Football or Basketball, recorded the largest increase in audience during the last World Cup, according to FIFA data. 
In addition to the sportive profile of the most important football competition in the world we paid a particular attention to the media coverage of this event. The development of digital technologies experienced in the 2010's competition, with the focus on social media, raised a number of expectations for the competition in 2014.

FIFA did not miss the opportunity to promote their biggest event by using various information platforms, marked by a multimedia profile, allowing us to send different content within instants. One such example was the official application developed by the institution that manages football all over the world. In June $12^{\text {th }}, 2014$, days before the official start of the competition, it was possible to find the following statement on FIFA's official website:

"The official app of the FIFA World Cup was launched with a worldwide exclusive coverage, which means that fans can take the biggest event of international football to where they are. The application, launched in December 2013, has been fully updated and is ready for the opening match of the tournament".

The justification used to create this official application, according to this organization, is the changing pattern of consumer's habits, promoted by the emergence of "second screen"tools: "Now consumers use smartphones and tablets to get more involved, especially in regard to sports content". Through the multiplatform reality, users were invited to follow the latest news, photos, and videos and to follow in real time, regardless of location, the best moments of each match.

The concern to create a symbiosis between mobile platforms and the potential of social media is even clearer if we consider the creation of the hashtags \#Copa2014 (\#Worldcup2014) and \#Façaparte (\#takeparte), together with others specifically developed for each match. This association between the various platforms, a kind of "virtual ticket"to the "FIFA Virtual Stadium", a social center, online and mobile, aimed to create a community environment enabling "interaction with friends, people all over the world, players, coaches and celebrities in social media feeds (...)".

The Global Stadium concept was the clear evidence of a multiplatform communication, taking advantage of the potential of a media environment marked by the convergence of content and platforms. The real-time and mul- 
timedia communication were the basis for the construction of a virtual community around this event:

"In the Global Stadium you are the first to watch the goals and can also follow the match with a minute by minute narration. Our external social media platforms also include Twitter, Facebook, YouTube and Instagram. We ask everyone to use the hashtag \# FaçaParte to all together experience FIFA World Cup".

If we consider the evaluation made by FIFA we see that this effort was rewarded by the good reception it had. On June $24^{\text {th }}$, 2014, even during the competition, Matt Stone, in charge of digital communication in FIFA, was clear by stating that: "We are on track to exceed the record audience of the FIFA World Cup 2010, 150 million people consuming content of FIFA".

The media, which took the opportunity raised from the World Cup to give their public a new approach to watch a football match, also followed the behaviour promoted by FIFA. Using the case of RTP and the BBC we understand a similar approach to that taken by FIFA.

With regard to RTP, the PSM in Portugal, the strategy developed for this competition held the promise to "show other football angles, either in direct matches or in the repetitions". Users were also asked to compare players and teams and share everything with their friends on social media. The reality of multiplatforms was even clearer by the presence on social media like Facebook, Twitter, YouTube and Instagram. As FIFA, hashtags were also created for the coverage of this competition.

Looking to the example from BBC, the idea of convergence and real-time information was even clearer. In an article entitled World Cup 2014: Digital Coverage was launched the following proposal: "From Manaus to Macclesfield and Rio to Rickmansworth, BBC Sport's dedicated live World Cup page will bring fans together and put them at the heart of the action. It will combine all the BBC's live digital coverage in one place, allowing audiences to access live video, radio and text updates wherever and whenever they want". For this very purpose to be fulfilled, the British operator intended to explore the potential of social networks, the BBC iPlayer and more traditional platforms such as television or radio.

Thus we believe that it is important to understand how the new digital information technologies were used for this competition. In this specific work 
we will pay a particular attention to the strategies used both on Twitter and Facebook. In a ambient information environment is important to understand how social media platforms are being used as an informative tool or as a promotional strategy.

\section{FROM THE CNN'S EFFECT TO THE TWITTER'S EFFECT: THE MICRO- BLOGGING AS AN INFORMATIVE TOOL}

Social media platforms have assumed a prominent role in how we base our lives on the Internet. Facebook and Twitter happen to be two good examples of a social media used in the information field.

According to the work of Boyd and Ellison (2007: 211), social media platforms act as web elements that allow citizens to (1) build a profile, which can be public or semi-public, within a bounded system, (2) articulate a list of other users with whom you can share a connection, and (3) view and navigate through your connections list or lists created by others within those systems. The same possibilities are in line with the idea of Mark Deuze (2013: 115), who explains that the use of the media by persons moves increasingly toward a social and real time technology: "The global adoption of online social networking is part of a larger trend in the dance between media and everyday life towards the predominance of artefacts always on and connected and activities that become the foundation for the arrangement of human sociability".

Despite the higher number of users of Facebook, is in relation to Twitter that we find more studies connecting it to the field of journalism. Analysing the phenomenon of Twitter can be an interesting process. It may help us to understand the emergence and development of new journalistic conventions and understand the impact that the microblogging networks can achieve (Vis, 2013). The profile of this meets one of the most important characteristics of journalism: be anywhere and anytime. Initially designed and built as a messaging system for mobile phones, it developed to the point of being today one of the most important elements in the digital information network. The limitation on the number of characters, 140 per message, is closely related to the compatibility it was intended to create, from the beginning, with the smartphones, elements that have reached a significant capital importance in the dissemination of instant messaging (Van Dijck, 2013). This messaging platform, shared among users, has designed a system that favours viral dis- 
tribution. Those features were proved during the plane crash in the Hudson River, which has strengthened Twitter as a capable element of disseminating last minute information, produced by journalists but also by citizens (Lasorsa, et al, 2011: 20). It is about a social media technology designed for online and instant dissemination of small pieces of data from official and unofficial sources. Part of the family of microblogs, they allow instant communication and the sharing and discussion of events as an expression of collective intelligence (Hermida, 2010).

The brevity of tweets and the increasing use of mobile devices are making more and more easy the process of sharing information from anywhere and at any time. In certain cases, Twitter anticipates the traditional media in the dissemination of breaking news. In addition, we must not forget to point out the multimedia profile of this platform, which, in addition to texts, allows the sharing of video and image. Thus, Bruns and Burgess (2012) intend that Twitter is the most prominent example of a social media technology that combines the convergence of social networking and the sharing of content production. For the authors, Twitter is both a social networking site and a stream of ambient information. We are able to measure this same trend if we look to the work of Alfred Hermida (2013), which gives us some points that help to understand the evolution of this social network as an information vehicle.

An early and clear example was the transformation of the welcoming message to its users. In 2006, at its launch, Twitter prompted users with the following question: "What are you doing?." By 2009, it was possible to read: "What is happening?" In 2012, the company website described this microblogging platform "as a real-time information network that connects you to the latest stories, ideas, opinions and news about what you find interesting". This subtle but meaningful change in Twitter's interface indicates a strategy that emphasises news and information over conversation. In other words, Twitter increasingly assumes rather as an informative tool than a social media platform.

Moreover, the limitation of characters per post (140 characters) makes Twitter a tool related to action, helping broadcasting events at the same time that they occur. Unlike Facebook, which, without a limit characters per post, allows a higher degree of development, the nature of Twitter is more related to the immediacy. That is why it is conceivable to understand Twitter as tool 
to be used in streets, during protests or strikes, and Facebook at home, in a calmer environment, allowing a deeper reflection.

Thus, we see that Twitter has developed as a system in which the news is reported, disseminated and shared online shortly, quickly and with a high degree of frequency (Hermida, 2010: 301). This is exactly what Nicola Bruno intends as the Twitter effect, comparing, at the same time, with the CNN effect:

"The Twitter effect is not only changing the way in which people communicate during crisis events, but also how big news organizations cover them. If the $\mathrm{CNN}$ effect required your own correspondents being on the ground in order to broadcast live footage, then the Twitter effect allows you to provide live coverage without any reporters on the ground, by simply newsgathering user-generated content available online".

While the CNN effect was crucial in centring media and political attention on a global crises, the Twitter effect promises to offer a more in-depth coverage of natural disasters and 'forgotten wars', providing visibility to threatened voices and political protests in less democratic countries.

\section{FROM AMBIENT JOURNALISM TO produsage}

One of the elements that we find at this level is the ambient journalism, which appears many times related to social media like Facebook and Twitter. Hermida (2010: 301) defines this concept as "an awareness system that offers diverse means to collect, communicate, share and display news and information, serving diverse purposes". In parallel, Bruns (2010: 5) intends ambient journalism as an "emerging analytical framework for journalists, informed by cognitive, cybernetic, and information systems research".

As a result, these platforms contribute to the pluralisation of narratives and could present new voices that are not heard through more conventional broadcast media (Papacharissi, 2014). At this level, Twitter, as an ambient journalism tool, provides a mix of news, information and comments that may be connected to current affairs, but without an established order. "This structure thus expands the number of different agents potentially involved in the production of journalistic products, most notably news (Vis, 2013: 29)". 
The role that audiences take in this reality, often reinforced by social media tools, is also highlighted when the team of researchers led by Dominic Lasorsa (2012: 20) explains that the very concept of journalism is becoming ambient, thanks to its ubiquity, often fragmented, and the collective effort involving the audience and journalists. Although most of the daily activities of media's users may not have value as news, when objects appear, a substantial amount of these activities is replaced by a concentrated effort to work the issue, similar to what is defined by journalists as being research. Increasingly influenced by the presence of the public, either through comments or content, the information environment becomes infected, opening new windows of opportunity for those who consume and produce information.

In this sense, we are faced with the emergence of a new concept: the produsage. This is an element that results from the sharing and conversational profile of online media, used by journalists, news organizations and individual users:

"The term is meant to describe, in a theoretically relevant manner, a set of practices that typically develop organically, as people share, forward, and comment on the news. While the resulting patterns of news sharing challenge our existing hierarchies of news production, consumption, and distribution, it is questionable whether people themselves consciously and constantly perceive themselves as produsers within the context of their everyday normality (Papacharissi, 2014: 3)".

This complex and social awareness network evolved beyond traditional journalism ecologies. The way these ecologies mix news production and consumption, changing the environment in which they operate, is understood as produsage. Thus, we can understand that the journalistic practices are changing. This happens due to the transition from a relatively closed system to a more open system, where the news may emerge through public observation, data and information that would be impossible to achieve in earlier times.

This new ecosystem is able to accommodate a wider range of news coming from different providers, employing techniques used in different media such as the press, broadcast, online, blogs and social media. In this very particular environment the flow of information moves with great fluidity through them (Picard, 2014). This same point is addressed by Axel Bruns (2011: 
122), when explains that there are two different aspects that, operating together, could change how journalistic work is performed: the continuous multiplication of channels available for publication and dissemination of news, especially since the emergence of the World Wide Web as a popular media, and the development of collaborative models for user participation and content creation, which currently are often summarized under the label of Web 2.0.

These arguments support the idea of Hermida who argues that the definition of ambient journalism can be applied to social media networks such as Twitter, with messages considered as both the representation of human activity and as artefacts:

"Twitter becomes a system where news is reported, disseminated and shared online in short, fast and frequent messages. It creates an ambient media system that displays abstracted information in a space occupied by the user. In this system, a user receives information in the periphery of their awareness (Hermida, 2010: $301) "$

In this sense social media platforms bring a set of opportunities to give a more active role for citizens in the information process. However it would be completely inadequate to analyse the influence that these platforms have in the field of information, just looking at citizens. Journalists are also influenced by these technologies, opening doors to new ways to put up with a digital environment in constantly bubbling. Furthermore, Henry Jenkins (2014: 284) suggests that more important than the role performed by individual citizens is the result of a commitment that is common and shared by multiple individuals as explained by Gilmor (2004: 54) when referring that new media technologies may contribute to a more diverse media environment, with different voices, that allow citizens to be heard not only as audience but as part of a media's community.

\section{POWER AND PARTICIPATION}

Taking into account all the possibilities made available by the new media technologies it is easy to engage in a speech of optimism regarding questions such as citizenship and participation. However, and using the work of Jen- 
kins (2006), we'd rather be cautious since whenever a new communication platform becomes available it is possible to find ultra optimistic speeches. In media and communication studies, especially where social and political engagement is on the research agenda, a lack of clarity or fixity is notable, making it hard to develop a critical approach regarding participation and new media technologies.

We aim to bring new elements to the debate around participation in the new media environment. In this new ecology the concept of participation and inclusion could be misunderstood. Thus, it is crucial to understand that "inclusion and participation are two different dimensions of public engagement" (Quick \& Feldman, 2011: 274). Considering the idea of inclusion, the two authors explain that it is mainly related to the links from different points of view that are established between groups or individuals and also the developed relationships based on common problems. On the other hand, when we look to the concept of participation, we see that this is much more oriented to the development of decision-making.

Peter Dahlgren (2014: 4) goes in the same direction, stressing that "participation is ultimately about power sharing and if this is structurally absent or systematically undermined, then whatever is being called participation must be seen with utmost skepticism, or indeed labeled fraudulent". Basically, "the difference of participation on the one hand, and access and interaction on the other is located within the key role that is attributed to power, and to equal(ized) power relations in decision-making process" (Carpentier, 2011: 131).

Both statements help to understand what Clemencia Rodriguez intends as citizens' media:

“(R)eferring to 'citizens' media' implies first that a collectivity is enacting its citizenship by actively intervening and transforming the established mediascape; second, that these media are contesting social codes, legitimized identities, and institutionalized social relations; and third, that these communication practices are empowering the community involved, to the point where these transformations and changes are possible (2001: 20)".

This approach is clearly important if we want to have a critical view towards new media technologies. The simple fact that we as citizens have 
more channels to make our voice heard does not automatically mean that we are participating. We risk ourselves to being no more than mere "citizens in waiting" (Livingstone, 2010). Supported by this idea, we may find that media outlets are often unable to effectively respond to comments and questions from followers, reinforcing, rather, a unidirectional profile for the dissemination of newly published content on the Internet pages (Bruns, 2012).

In some particular cases, citizens' actions are seen as an opportunity to gather a higher number of audiences and the new platforms can be perceived as a new way to achieve new incomes. Even with opportunities raised by main media chains such as CNN, with the iReport, it is not common to find content developed by citizens. The few exceptions are related to protests and natural disasters and it normally happens when media companies do not have journalists on that field and citizens are used in order to benefit those main chains (Kperogi, 2010: 326). Even when we look to Facebook and Twitter as an opportunity to raise new and different voices, we can see that the traditional elites are using these new channels to achieve new followers, extending their power networks to this new reality (Willimans \& Carpini, 2004: 1214).

One of these examples is related with the way in which media outlets use Twitter, not as an informative tool but with a promotional element. Much of the content used on social media is not primarily motivated to inform followers about the main issues of the day, but direct them to the main sites in order to achieve more views and better audiences' results. In this case, what we understand is that Twitter is not used as an information platform, promoting real power and participation, but as a means to promote the existing contents, sending followers to the main sites of these organizations (Vis, 2013). Instead of contributing to the creation and development of communities, we are facing the development of audiences:

"An audience is characterized by a unidirectional connection between transmitter and receiver (one to many) and the absence of relationships between receptors. This type of relationship is the characteristic model in traditional media. In the case of communities recorded a two-way communication (many to many), there is some kind of close relationship between its members (Canavilhas, 2010: 6)". 
Observing these elements it is possible to understand that the opportunities raised by new media technologies to achieve the "promise of the empowered user", one that is not "a passive and separate spectator" anymore, but rather an autonomous and capable of "interact in a common world", must be warily taken (Lopes, et al., 2013: 38a).

\section{The World Cup of Social Media: More from LeSS OR LeSS FROM MORE?}

a) Methodological approach

As it was possible to understand with the previous references, the FIFA World Cup 2014 was a global event marked by the multiplatform profile in which information flew through all the continents. A lot of effort was done by FIFA, and then followed by several different media companies worldwide, to take the advantages promoted by digital platforms.

In this specific study we aim to understand how social media platforms were used, both by producers and users, during the most important event in the world, regarding football. We have selected the platforms Twitter and Facebook to understand how information was posted on these two social media platforms and the strategies created for citizens' engagement.

In order to have a broader perspective, we choose a total of seven countries and 13 different media outlets ${ }^{2}$. Our main criterion was to select two media per country. On one hand it had to be a media platform specifically dedicated to sport, on the other hand, we selected the outlets that had acquired the rights to broadcast the matches of this event. Then we paid attention to each one of

2. Argentina: Olé Belgium: RTBF and Sportwereld (SW) ; Brazil: ESPN and Globo; Spain: Marca and Mediaset; France: L'Équipe and TF1; England: BBC and Sky Sports; Portugal: RTP and Maisfutebol (MF). The only exception here was Argentina where we only have selected a media company. This work is part of a more complex analysis that includes other informative platforms such as mobile apps and websites. Taking into account the limit that Apple imposes on the number of stores in the same peripheral it was not always possible to analyse all the cases we wanted. Thus, we only had the option to select one media outlet from Argentina. After deciding the media companies to integrate on our study, we decided to analyse all the games of each one of the involved countries. So, for example, to understand the coverage of the Portuguese national team we used the two Portuguese media companies, and so on. 
the games of the represented countries, making a total of 32 games and the posts published during those games: 3195 on Twitter and 665 on Facebook ${ }^{3}$.

To make our sample viable, we divided the game in three different periods of time ${ }^{4}$ : preview, game and after-game.

This sample was decided to answer to the following research questions:

R1: Did Twitter and Facebook contribute to a more multimedia reality?

R2: Did social media prove to be a useful tool regarding users' participation?

R3: Is there any connection between social media sites and other informative platforms?

After deciding the sample and the research questions to be answered, we have applied three different variables to guide our experience.

V1: Continuity: the total number of posts published by each of the media during the analysed matches;

V2: Multimedia: the profile of the content offered by each of the media forming part of this work;

V3: Autonomy: the possibilities for users' integration regarding a more active consumption.

b) Continuity and multimedia: A football match through the lenses of Social Media platforms

The main objective with this variable was to realize how the different media companies used both Twitter and Facebook to inform their users during the games. We have also tried to understand the variation of the coverage during the different moments of the game: preview, match and after-match.

3. Twitter: Argentina (829); Belgium (427); Brazil (533); Spain (237); France (349); England (325); Portugal (495). Facebook: Argentina (16); Belgium (132); Brazil (151); Spain (57); France (62); England (24); Portugal (223).

4. All the posts collected during the hour before the start of the match were included in the category pre-match. The posts made during the game are inserted in the match. Finally, the category after-match represents all the content published in the one hour after the match. 
Figure 1. Average of posts per game.

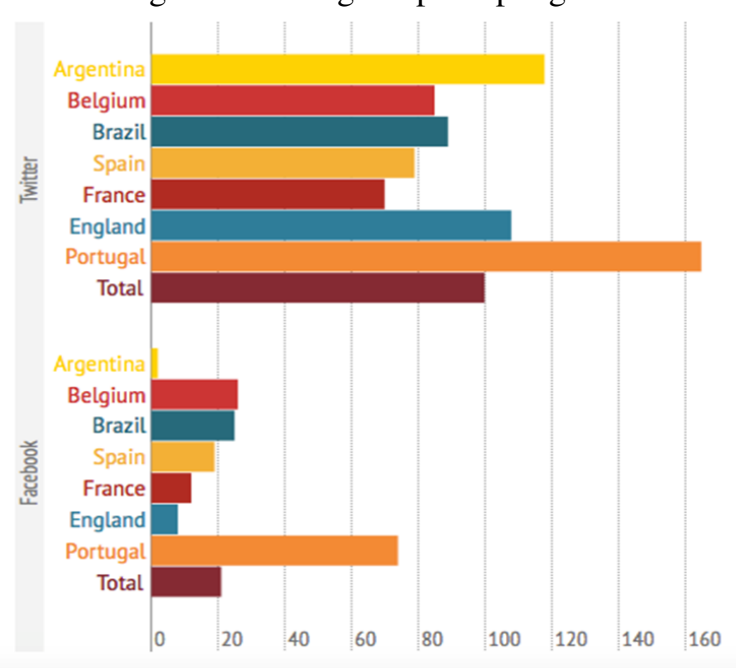

Source: Own source.

Looking to the average of posts per game we understand that there is a much bigger number of post on Twitter than on Facebook ${ }^{5}$. Thanks to its profile that allows live reporting, almost all the outlets used Twitter as a way to narrate some of the most important moments of each game. For instance, Olé, from Argentina, used this platform as a minute-by-minute tool. Since this outlet does not have an app with these characteristics, Twitter was used with that purpose. Assuming that each analysed game has, at least, ninety minutes, it is possible to understand that the average of posts on Twitter is more than one per game, contrasting with the numbers of Facebook.

Analysing these same numbers per country, Portugal and Argentina are the two outstanding countries. If we have already highlighted the performance of Olé, it is also possible to refer how MF, from Portugal, used Twitter. Even having an app designed for smartphones and tablets, this Portuguese media

5. Twitter: Argentina (118); Belgium (85); Brazil (89); Spain (79); France (70); England (108); Portugal (165). Facebook: Argentina (2); Belgium (26); Brazil (25); Spain (19); France (12); England (8); Portugal (74). 
used Twitter to give their users a different perspective about the games of the Portuguese national team.

Once again it is clear the difference between Twitter and Facebook, with all the media having less posts per game in the second platform.

Figure 2. Number of posts per moment of the game.

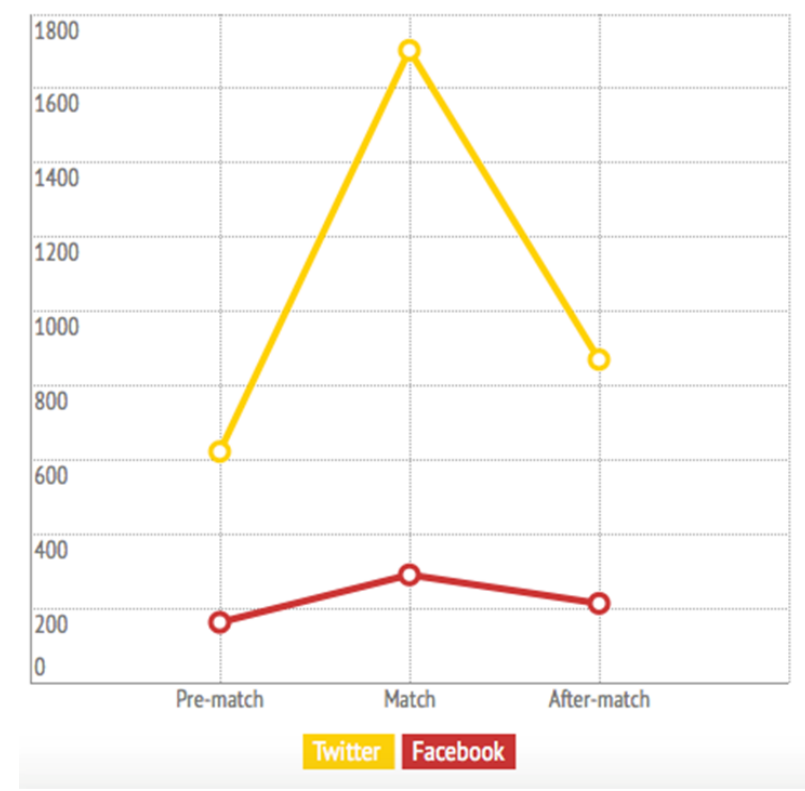

Source: Own source.

Looking to the second figure we understand that the different media outlets used the same pattern during the games ${ }^{6}$. The period of time with more posts was the game. It is mainly possible due to: the total time of that period, at least nineteen minutes instead of the sixty of the other two; it is during this period that the game happens. The period pre-match and after-match were mainly used to call the attention of users for the game in the main platforms of these outlets, assuming a clear promotion profile.

6. Twitter: Pre-match: 412; Match: 1292; After- match: 697. Facebook: Pre-match: 162; Match:290; After-match: 213. 
Figure 3. Thematic of the posts.

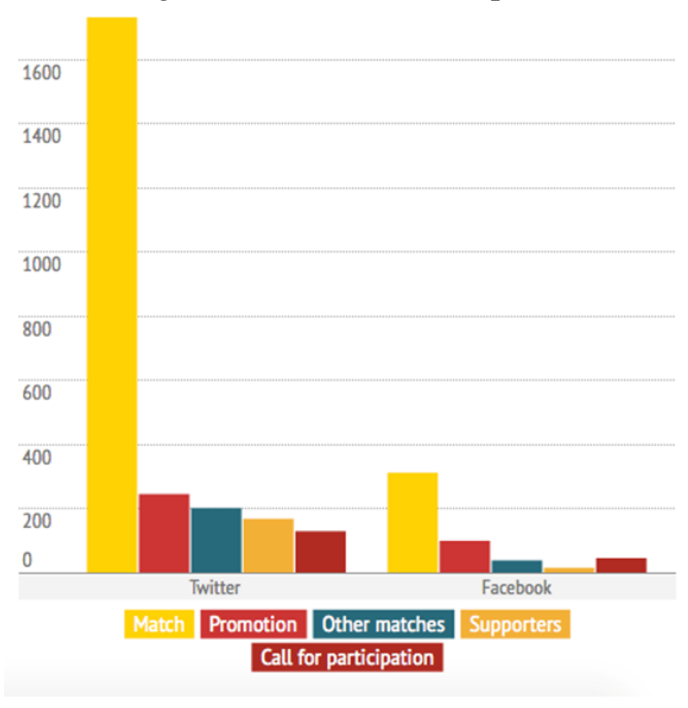

Source: Own source.

In this research we have also tried to understand the most common theme in the analysed posts ${ }^{7}$. As it was expected, the posts regarding the matches were found in most of the cases, following the promotional posts. This last kind of post was used to gather audiences to other platforms: TV, Websites or mobile apps. It is also interesting to mention the considerable number of posts related to supporters. In these posts, media outlets used content provided from their followers, normally after inviting them to send pictures to show how they were watching a certain match. However, even if this was a common topic among all the analysed posts, we rarely found an answer made by the journalists. This could be understood like an echo-chamber room, since users spent part of their time speaking to themselves.

7. Twitter: Match: 1733; Promotion: 245; Other matches: 201; Supporters: 168; Call for participation: 129. Facebook: Match: 312; Promotion: 99; Other matches: 38; Supporters: 15; Call for participations: 45 . 
Figure 4. Main content on the posts.

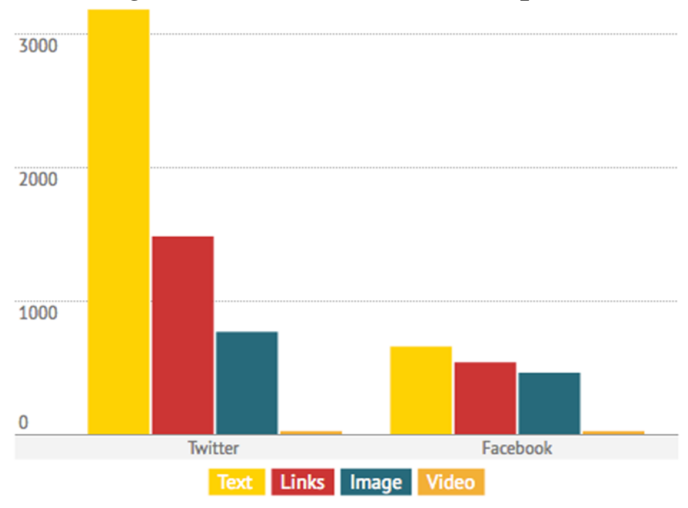

Source: Own source.

In figure 4, we can understand what was the most common content delivered by Facebook and Twitter ${ }^{8}$. Text was found in almost all the posts on both platforms. Curiously, the second type of content found in this study was the link. This can be related to the number of promotional posts, since these links were commonly used to guide users to the main websites, instead of informing them about this competition. Looking to the numbers of image and video it is clear that there is still a long way in order to have a multimedia environment on these both platforms.

c) Twitter and Facebook: New opportunities for citizens' engagement?

8. Twitter: Text: 3179; Links: 1471; Image: 766; Video: 23. Facebook: Text:657; Links: 538; Image: 460; Video: 23. 
Figure 5. Total number of shares.

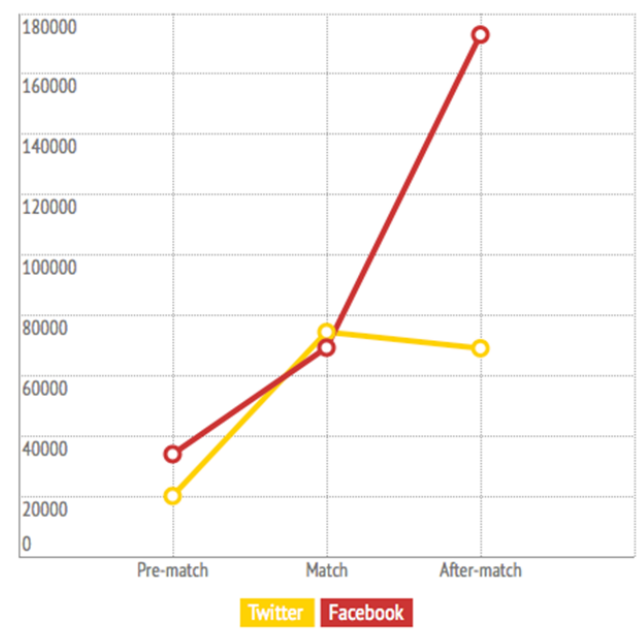

Source: Own source.

Figure 6. Total number of likes.

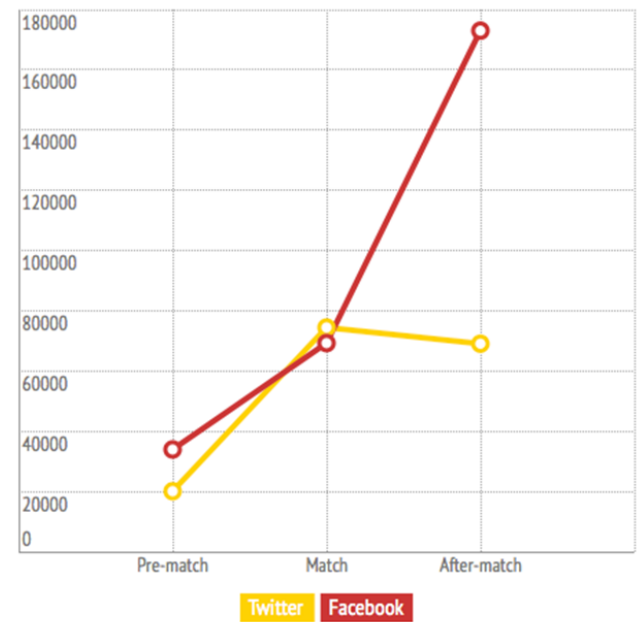

Source: Own source. 
Figure 7. Total number of comments.

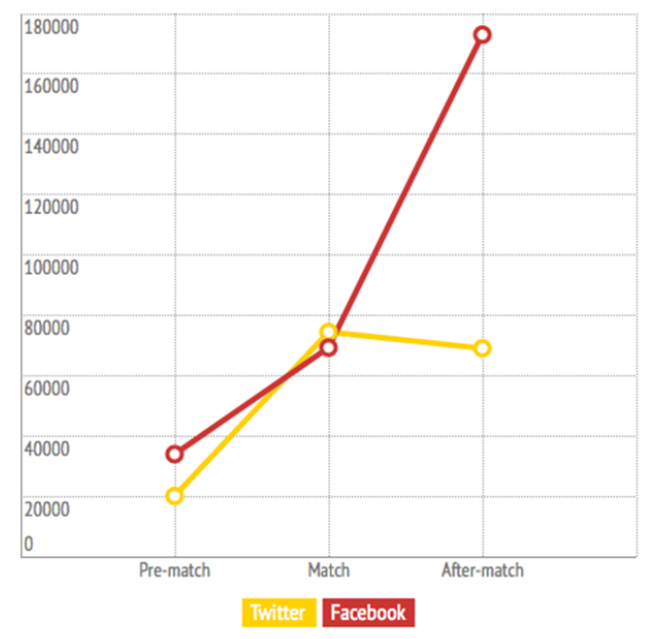

Source: Own source.

During the second stage of our empirical analysis, we tried to understand how users engaged using both Facebook and Twitter. First, we can notice more engagement signs on Facebook than on Twitter ${ }^{9}$. The first platform was used in a more regular way than Twitter. Then, it becomes possible to highlight the different pattern of both platforms. While Twitter reached its peak during the match, Facebook was more use after the match. As we have stated before, Twitter is commonly used as a reporting tool. Due to the limit of characters per post, we can understand Twitter as being a tool for live events, reporting at the same time as it is happening. On the other hand, Facebook without limits in the number of characters per post, allows a more elaborated effort.

Facebook was more used as a like platform, while Twitter had more engagement through the share button. If we pay a closer attention to how people used both platforms, we can understand that the more elaborated possibility for engagement, the comment, was the less used. Moreover, we can assume

9. Shares: Facebook: 276220; Twitter: 163567. Likes: Facebook: 2108804; Twitter: 89204. Comments: Facebook: 175553. 
that even when there is a possibility for users to have a more developed and active role in the informative process, they do not always take that opportunity.

\section{Discussion}

FIFA World Cup represented both for organizers and for media companies a great opportunity to take advantages of the opportunities made available by media technologies, mainly mobile tools and social media platforms.

Regarding these developments, specifically speaking about social media, we tried, in the first RQ to understand how media companies understood the opportunities created for a more multimedia approach. However, and following some of the results from previous analyses (Neto, 2014), the multimedia reality promoted by new media platforms still has a long path ahead before being a reality. Thus, we observed that along with text the most common content in the analysed posts was the link. This result confirms some of the positions presented in our theoretical approach, relating the utilization of social media as a way to achieve more visits on the main websites, instead of being an information tool. Moreover, due to the low numbers of video and images we can also understand that it is still not possible to talk about a truly convergent reality.

In the RQ2 we have tried to understand what were the opportunities created for participation by users. Even with the posts using material from users, when we face the high number of promotional posts, it is possible to explains that social media platforms were used to created an audience instead of a real community. The low number of answers by journalists to the posts made by users also reflects the audience reality. Thus, instead of contribution to real participation, social media tools were used as a way to perpetuate the situation of a empowered user, like in other researchers presented about sport and new media technologies (Lopes, et al., 2013b; Neto \& Lopes, 2014 ).

Taking into account the idea of a global stadium promoted by FIFA, in the RQ3 we tried to understand how media outlets followed this pattern. Apart from the links with connections to the main platforms, with a clear promotional profile, we did not see any major signs of convergence between all the platforms. Instead, the global stadium was substituted by individual stadiums for the same games, annulling any possibility of a common approach for different platfroms, the truly essence of the global stadium. 
Comparing the numbers of Facebook and Twitter becomes easier to understand why Twitter was used in different analyses to understand the relation between social media and political conflits (Meraz \& Papacharissi, 2013; Vis, 2013; França, 2014). The mobile and direct profile of Twitter enables it to be a tool for live information. It's reinforced with the limit of characters per post, making Twitter a more street tools, whereas Facebook is more used for elaborated posts. It's evident in figure 3, where the difference between posts related to the matches and other posts is bigger than on Facebook. Moreover, Twitter was also used as platform to narrate the different matches when the media companies did not have an app for mobile tools.

\section{REFERENCES}

Boyd, D. M. \& Ellison, N. B. (2007). Social network sites: definition, history, and scholarship. Journal of Computer-Mediated Communication, 13(1): 210-230. DOI: 10.1111/j.1083-6101.2007.00393.x

Burns, A. (2010). Oblique strategies for ambient journalism. M/c Journal, 13(2).

Bruns, A. (2011). Gatekeeping, gatewatching, realimentação em tempo real: novos desafios para o jornalismo. Brazilian Journalism Research, 7(2): 119-140.

Bruns, A. (2012). Journalists and Twitter: how australian news organisations adapt to a new medium. Media International Australia Incorporating Culture and Policy, (144): 97-107.

Bruns, A. \& Burgess, J. (2012). Researching news discussion on Twitter: new methodologies. Journalism Studies, 13(5-6): 801-814.

Canavilhas, J. (2010). Do gatekeeping ao gatewatcher: o papel das redes sociais no ecossistema mediático. In II Congreso Internacional Comunicación, vol. 3. Universidad de Salamanca. Retrieved from http://novosmed ios.org/xornalismo/wp-content/uploads/2014/01/mudanzas-gardabarreir as.pdf .

Carpentier, N. (2011). Media and participation: a site of ideological-democratic struggle. Bristol: Intellect Books. 
Dahlgren, P. (2014). Participation and alternative democracy: social media and their contingencies. In P. Serra, E. Camilo \& G. Gonçalves (Eds.), Political participation and WEB 2.0 (pp. 61-87). Covilhã: LabCom.

Deuze, M. (2013). Viver como um zumbi na mídia (é o único meio de sobreviver). MATRIZes, 7(2): 113-129.

França, L. C. M. (2014). “Occupy Brazil”: configurando uma rede de reações. Culturas Midiáticas, 7(1).

Hermida, A. (2010). TWITTERING THE NEWS: the emergence of ambient journalism. Journalism Practice, 4(3): 297-308. DOI: 10.1080/1751278 1003640703

Hermida, A. (2013). \#JOURNALISM: reconfiguring journalism research about Twitter, one tweet at a time. Digital Journalism, 1(3): 295-313. DOI: 10.1080/21670811.2013.808456

Jenkins, H. (2006). Convergence culture: where old and new media collide. New York: University Press.

Jenkins, H. (2014). Rethinking convergence/culture. Cultural Studies, 28(2): 267-297. DOI: 10.1080/09502386.2013.801579

Kperogi, F. A. (2011). Cooperation with the corporation? CNN and the hegemonic cooptation of citizen journalism through iReport.com. New Media \& Society, 13(2): 314-329. DOI: 10.1177/1461444810373530

Lasorsa, D. L.; Lewis, S. C. \& Holton, A. E. (2012). NORMALIZING TwITTER: journalism practice in an emerging communication space. Journalism Studies, 13(1): 19-36. DOI: 10.1080/1461670X.2011.571825.

Livingstone, S. (2010). Interactivity and participation on the Internet: young people's response to the civic sphere. In P. Dahlgren (Ed.), Young citizens and new media: learning for democratic participation (pp. 103-124). London: Routledge.

Lopes, F.; Loureiro, L. \& Neto, I. (2013a). O real (ainda) mora aqui?. Braga: CECS.

Lopes, F.; Loureiro, L. \& Neto, I. (2013b). O ecrã da (hiper) televisão: novos olhares a partir das emissões dedicadas ao Euro 2012 na TV portuguesa. Observatorio $\left(O B S^{*}\right), 7(3)$ : 35-57. 
Meraz, S. \& Papacharissi, Z. (2013). Networked gatekeeping and networked framing on \#Egypt. The International Journal of Press/Politics, 18(2): 138-166. DOI: $10.1177 / 1940161212474472$

Neto, I. (2014). Da TV para o tablet: o processo de convergência dos media portugueses no contexto dos dispositivos de informação móveis. Derecom, (16), 6 .

Neto, I. \& Lopes, F. (2014). Do estádio para a mão: a narração dos jogos da fase final da Liga dos Campeões através das apps para o iPhone. Observatorio $\left(O B S^{*}\right), 8(4)$.

Picard, R. G. (2014). Twilight or new dawn of journalism?: Evidence from the changing news ecosystem. Journalism Studies, 15(5): 500-510. DOI: 10.1080/1461670X.2014.895530

Papacharissi, Z. (2014). Toward new journalism(s): affective news, hybridity, and liminal spaces. Journalism Studies, 16(1): 27-40. DOI: 10.1177/194 0161212474472

Quick, K. S. \& Feldman, M. S. (2011). Distinguishing participation and inclusion. Journal of Planning Education and Research, 31(3): 272-290. DOI: $10.1177 / 0739456 X 11410979$

Rodríguez, C. (2001). Fissures in the mediascape: an international study of citizens' media. NJ: Hampton Press.

Van Dijck, J. (2013). The internet in flux: Twitter and the interpretative flexibility of microblogging. In F. Lee, L. Leung, J. L. Qiu \& D. Ch (Eds.), Frontiers in new media research (pp. 222-241). New York, NY: Routledge.

Vis, F. (2013). TWITTER AS A REPORTING TOOL FOR BREAKING NEWS: journalists tweeting the 2011 UK riots. Digital Journalism, 1(1): 27-47. DOI: $10.1080 / 21670811.2012 .741316$

Williams, B. A. \& Delli Carpini, M. X. (2004). Monica and Bill all the time and everywhere: the collapse of gatekeeping and agenda setting in the new media environment. American Behavioral Scientist, 47(9): 12081230. DOI: $10.1177 / 0002764203262344$ 


\section{Online Sources}

Eurodata TV worlwide. Yearly Sports Key Facts 2014 (September 2013August 2014). Accessed 10 october 2014. www.mediametrie.com/press e/communiques/yearly-sports-key-facts-2014-september-2013-august-2 014.php?id=1141

A Copa do Mundo. De todo o mundo. Accessed 12 october 2014. www.nomi nuto.com/mobile/noticias/copa-do-mundo/a-copa-do-mundo-de-todo-omundo/112335/

Clássico em Manaus bate recorde de audiência na Inglaterra e Itália, diz Fifa. Accessed 12 october 2014 http://globoesporte.globo.com/am/copa-do-m undo/noticia/2014/06/classico-em-manaus-bate-recorde-de-audiencia-n a-inglaterra-e-italia-diz-fifa.html

Primeiros jogos da Copa do Mundo quebram recordes de audiência. Accessed 12 october 2014 http://esportes.terra.com.br/futebol/copa-2014/fifaprimeira-rodada-da-copa-quebra-recordes-de-audiencia,c85b34742ebb6 410VgnVCM3000009af154d0RCRD.html

Estádio global da FIFA abre as portas para que o torcedor \#FAÇAPARTE da \#COPA2014. Accessed 12 october 2014. www.secopa.ba.gov.br/noticias /estádio-global-da-fifa-abre-portas-para-que-o-torcedor-façaparte-da-co pa2014

Fifa oferece conteúdo conectado a redes sociais. Accessed 12 october 2014. www.panoramaaudiovisual.com.br/2014-06-fifa-oferece-conteudo-cone ctado-a-redes-sociais-13550

Mundial somos nós. Accessed 14 october 2014. http://media.rtp.pt/projetos/a pp_mundial/

Details of BBC coverage of the 2014 FIFA World Cup across TV, radio and online. Accessed 14 october 2014. www.bbc.co.uk/mediacentre/mediap acks/worldcup2014/digital

SIC e TVI rompem negociações do Mundial com RTP. Accessed 17 january $2015 \mathrm{http}: / /$ expresso.sapo.pt/sic-e-tvi-rompem-negociacoes-do-mundialcom-rtp=f852478 